\title{
Profile of Visual Thinking of Mathematics Teachers Candidates in Designing STEM-Based Learning
}

\author{
Darmadi \\ Universitas PGRI Madiun, Mathematics Education Department, Universitas PGRI Madiun, Madiun, Indonesia \\ darmadi.mathedu@unipma.ac.id
}

\begin{abstract}
It can be said that STEM is the actualization of thematic learning. Prospective teachers in general and prospective mathematics teachers in particular need to learn to design STEM-based learning. This paper provides an overview of visual thinking of prospective mathematics teacher students in designing STEM-based learning. The research method used is an explorative descriptive research method with a qualitative approach. The subject of research is the $5^{\text {th }}$ semester student of the Mathematics Education Study Program of Universitas PGRI Madiun academic year 2019/2020. Data collection is done with in-depth task-based interviews. Triangulation time is used to obtain saturation and validity and data. Valid data is analyzed by coding, data reduction, data exposure, categorization, and abstraction so that conclusions are obtained. The results showed that in the visual thought of designing STEM-based learning mathematics teacher candidates use contextually visualizations on the objectives, activities, times, and tools to be used in learning.
\end{abstract}

Keywords: thinking, visuals, design, learning, STEM

\section{INTRODUCTION}

STEM learning approaches accordance with the 4 basic skills needed for the 21st Century, namely: critical thinking and problem solving, creativity and innovation, communication, and collaboration. Students have skills in critical thinking and problem solving; it means that after learning students have critical thinking in solving problems. Students have skills in creativity and innovation; it means that after learning students have creativity and innovation. Students have skills in communication; it means that after learning students have the ability to hear, read, speak and write using various media. Students have skills in collaboration; it means that after learning students have the ability to collaborate and respect others.

STEM (Science, Technology, Engineering, and Mathematics) was an educational approach that uses knowledge, technology, engineering and mathematics comprehensively for problem solving. Science was the study of nature as the basis of technology. Technology deals with innovations that are used to meet needs so as to make life better and safer. Engineering was concerned with the knowledge and application of scientific principles to obtain scientific, economic, social, design and construction knowledge, equipment, systems, materials and processes that benefit humans economically and are environmentally friendly. Mathematics refers more to the science of patterns and relationships that provide the language of technology, science, and engineering.
Some experts develop STEM as STEAM (Science, Technology, Engineering, Arts, and Mathematics). The end result expected from implementing STEM or STEAM was that students take risks and engage in experiential learning, persist in problem solving, embrace collaboration, and work through the creative process. The results of previous research indicate that STEM can improve learning outcomes and student interest [1].

There are 3 approaches STEM and 9 perspectives on STEM [2], Three approaches STEM that are usually used in STEM learning, namely: the silos approach, the embedded approach, and the integrated approach. In the silos approach, each STEM discipline was taught separately to maintain the domain of knowledge within the boundaries of each discipline. In the embedded approach, STEM learning emphasizes maintaining the integrity of the subject matter, instead of focusing on interdisciplinary subjects, the material in the embedded approach is not designed to be evaluated or assessed. In an integrated approach, each STEM field was taught as if it were integrated into one subject. STEM integration can be implemented most successfully when mathematics and science teachers work together both in a single classroom and in multiple classrooms. There are 9 perspectives on STEM, namely: STEM equals science (or mathematics), STEM means both science and mathematics, STEM means science and incorporates technology, engineering, or math. STEM equals a quartet of separate disciplines. STEM means science and math are connected by one technology or engineering program. STEM means coordination across disciplines. STEM means combining 
two or three disciplines. STEM means complementary overlapping across disciplines. STEM means a trans disciplinary course or program.

There are several benefits of STEM-based learning. STEM-based learning can hone students' skills in thinking critically, creatively, logically, innovatively, and productively. STEM-based learning can instill a spirit of cooperation among students in solving problems. STEMbased learning introduces students to the perspective of the world of work so they can prepare for it. STEM-based learning utilizes technology to create and communicate innovative solutions. STEM is a medium to develop students' ability to find and solve problems. STEM is a medium for realizing learning experiences through increasing the capacities and skills of students.

A problem can be arises in STEM learning. The problem that is often faced in implementing STEM is the need to understand the similarity of thinking from the point of view of different disciplines. Gender disparities in STEM occur because women are less likely to pursue STEM, but racial disparities occur because fewer black and Hispanic students are prepared for STEM in high school [3].

Visualization can be used to design STEM learning.. Visualization has proven to be of great help in learning mathematics [4] [5]. Visualization makes it easier for students to understand concepts or definitions [6]. Visualization makes it easier for students to solve problems [7]. Until this article was written, researchers had not found any research on the profile of visual thinking of mathematics teacher candidates in designing STEM-based learning.

The problem that is the focus of this article is how the profile of visual thinking of mathematics teacher candidates in designing STEM-based learning. This is important because prospective mathematics teachers will continue to implement STEM in learning. If not, we will not know what student teacher candidates think about designing STEM learning.

\section{METHOD}

To get profile of visual thinking of mathematics teacher's candidates in designing STEM-based learning, a descriptive exploratory research method with qualitative approach was used. The research subjects were students of mathematics education department of Universitas PGRI Madiun.

Data collection was carried out by using a task-based interview technique. The task given was to ask the subject to make or design STEM-based learning with the theme of gardening for grade 2 elementary school students. The assignments ware collected after the students have finished designing STEM-based learning. The assignments give the results of student work.
The results of student work ware analyzed to determine which subject can explain and provide information about the profile of visual thinking in designing STEM-based learning.

After the subject was selected, the next step is to give a task that is identical to the same problem, namely designing STEM-based learning.

In addition, students were interviewed for in-depth information. Interviews were conducted again after a week or two later to ensure that the data obtained were saturated data. This data is also used for the time triangulation. Confirmation is possible even though the data has been compiled to obtain the depth and breadth of the data. Even though the data collection is repeated and in-depth, the naturalness of the data is maintained.

After the data is obtained, the data is presented and time triangulated to obtain valid data. Valid data are then analyzed by coding, reduction, and categorization. Coding is done to make it easier to search the data. Data reduction is used to obtain relevant data with visual thinking profiles in designing STEM-based learning. Categorization is used to get a clear profile to get a conclusion.

Although the conclusions obtained are based on data from several subjects, the research results can be used to generalize if they are accepted by the general public [8].

\section{RESULTS AND DISCUSSION}

There were 20 students who participated as respondents in this study. There was some step of respondents to design STEM-based learning with the theme of creating a school garden. The first step of most students to design STEM-based learning with the theme of creating a school garden was describing the garden design. To describe the garden design, students think visually.

After getting an overview of the available land, students examine the STEM elements that will be used. In this first step, the subject visualizes the target. The target in question is the shape and size of the garden land in the target school. After visualizing the target, the subject visualizes the activity. The subject thinks of learning activities to complete the garden project with STEM related learning activities.

Simultaneously with thinking about the activities to be carried out, the subject thinks about the tools used. In addition, the subject also thought about the allocation of time for each activity. To represent activities, tools, and time, the subject imagines or thinks visually. One of the elements of STEM learning is science. Science is the study of nature as the basis of technology. Some of the scientific studies proposed by students included teaching the importance of gardens, teaching various kinds of flowers, teaching various toga (family medicinal plants), 
teaching plant parts, and teaching plant growth. This is in accordance with the class 2 SD / MI science subject matter which consists of 5 chapters, namely: 1) knowing animals and plants, 2) animals and plants around us, 3) solid and liquid objects, 4) energy sources around us, and 5) the sun and our life [9].

One of the STEM learning criteria is the presence of technology elements. The technology in question is related to innovation. Innovation is an idea or ideas that have never existed. An idea or theory is called innovation if it is unique, new, planned, and has a purpose. Innovation must have characteristics that are not owned or exist in previous ideas or ideas. Innovation is a new idea or idea that has never been expressed before. An innovation is deliberately made and planned to develop certain objects. So, the last characteristic that must be present in innovation is to have a purpose. The technology obtained by students is to create or be involved in making gardens.

One of the elements of STEM learning is engineering. Engineering is concerned with the knowledge and application of scientific principles to obtain scientific, economic, social, design and construction knowledge, equipment, systems, materials and processes that benefit humans economically and are environmentally friendly. In this lesson, students can apply scientific principles, such as: how to grow plants, how to mix cement with water, how to use woodworking tools such as saws and so on [10].

One of the elements of STEM learning is mathematics. Mathematics is the science of patterns and relationships so that it becomes the language of technology, science and engineering. Students plan mathematical elements in learning as follows measurement, area, area division, perimeter, calculations in designing gardens. This is in accordance with the mathematics material for grade $2 \mathrm{SD} / \mathrm{MI}$. The complete material consists of several chapters, namely: 1) counting numbers (whole numbers, addition and subtraction), 2) measurements (time and length), 3) measuring length and weight, 4 ) calculating numbers (sorting numbers), 5) addition and subtraction, 6) measuring time, 7) counting numbers (multiplication and division), and 8) flat shapes [11]. Mathematics is also related to [12] [13]

After paying attention to the STEM elements, subject design STEM-based learning by paying attention to the activities of learning, the teachers or experts needed, and the time. The average time required for implementing STEM-based learning as above was 1 day. In order not to interfere with other learning, it was recommended that the implementation is Saturday.

One of the final results expected from the application of STEM is that students have the courage to take risks. From in-depth interview for the learning activity, students were trained to dare to take risks in making gardens. If students do not have the courage to make a garden, the garden project will not materialize.

One of the final outcomes that expected from the application of STEM was students involved in experiential learning. From in-depth interview for the learning activity, students are involved in learning. If students are not involved in learning, the gardening project will not occur. Each student is given a task to complete according to the time available. If there are students who do not do their assignments, the group garden will not be successful and the classroom garden will not be successful.

One of the final results expected from the application of STEM is students persist in problem solving. From indepth interview for the learning activity, students persist in problem solving. In every activity there is a problem, if students do not persist in solving the problem, the project to make a garden will fail.

One of the final results expected from the application of STEM is that students are able to collaborate. From indepth interview for the learning activity, students are required to collaborate. If students do not collaborate, the project to make a garden will also not materialize. Each group makes its own assignment in the group. So that if there are students who do not collaborate, the group garden will not be good and the classroom garden will not be successful.

One of the expected outcomes of implementing STEM is that students work through a creative process. From in-depth interview for the learning activity, students work through a creative process. If students are not creative, group gardens and classroom gardens will not be varied and good. The project results are not good.

The learning designs offered by subjects match with the STEM-based learning concept. The profile of the visual thinking of mathematics teacher candidates in designing STEM-based learning is contextual visualization. The contextual visualization of mathematics teacher candidates can be described as follows.

The first visualization performed by prospective mathematics teacher students is to visualize the target The target visualization in question is the visualization of the school to be treated, namely using STEM. This is important, so that the learning that is designed can be used in the target school and the theme chosen is right for learning.

The second visualization performed by prospective mathematics teacher students is visualizing activities. In accordance with the determined theme (gardening), students visualize the activities that must be carried out, such as the need to explain the importance of gardening, how to design a garden from the available land, how to make and maintain a garden. 


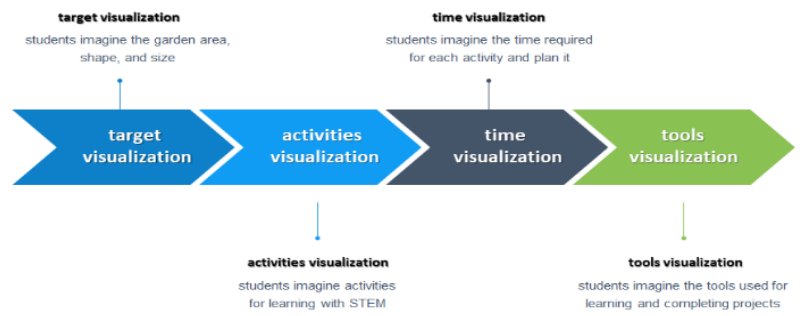

The visual thinking in designing STEM-based learning

The third visualization that is done by prospective mathematics teacher students to design STEM-based learning is the visualization of time. Time visualization is needed so that the learning is complete.

The fourth visualization that is done by prospective mathematics teacher students to design STEM-based learning is to visualize the tools. The tools in question are learning tools that will be used in learning. To explain STEM-based learning and the importance of gardening, a projector and computer are needed. Projectors and computers are needed to save time in learning. To design the garden, markers and a ruler are needed. To make a garden, tools such as a hammer, nails, wood, saw, hoe, and so on are needed. To design, a ruler is needed (students imagine a ruler), drawing paper (students imagine drawing paper), a work table (students imagine a work desk), and so on. To make a garden, a wooden fence is needed (students imagine wood for a fence), plants (students imagine a plant or flower to be planted), a hammer (students imagine a hammer, etc. Visualization of tools is needed to ensure the implementation of a predetermined project.

Visualization helps students in designing STEM learning. This can be seen from the interviews every step of the way to design STEM learning. Mathematics teacher candidates use contextually visualizations on the objectives, activities, tools, and times to be used in learning.

\section{CONCLUSION}

The results showed that in the visual thought of designing STEM-based learning mathematics teacher candidates use contextually visualizations on the objectives, activities, tools, and times to be used in learning.

This learning design is very interesting because it in accordance with the STEM criteria and provides the results expected from STEM learning. Thank you to the Ministry of Research, Technology and Higher Education who has funded this research.

\section{REFERENCES}

[1] Rena F. Subotnik, Robert H. Tai, Rochelle Rickoff \& John Almarode, "Specialized Public High
Schools of Science, Mathematics, and Technology and the STEM Pipeline: What Do We Know Now and What Will We Know in 5 Years?" Roeper Review Volume 32, Issue 1: Stem High Schools, 2009

[2] Gillian H. Roehrig, Tamara J. Moore, Hui-Hui Wang, Mi Sun Park, "Is Adding the E Enough? Investigating the Impact of K-12 Engineering Standards on the Implementation of STEM Integration", School Science and Mathematics", volume 112, issue 1, January 2012, pp. 31-44

[3] Will Tyson, Reginald Lee, Kathryn M. Borman \& Mary Ann Hanson, "Science, Technology, Engineering, and Mathematics (STEM) Pathways: High School Science and Math Coursework and Postsecondary Degree Attainment.", Journal of Education for Students Placed at Risk (JESPAR), volume 12, 2007, iIssue 3, pp 243-270, published online: 05 Dec 2007

[4] Bingolbali, E. \& Monaghan, J. "Concept image revisited. Educational Studies of Mathematics", 68(1), 2008, pp. 19-35

[5] Bingolbali, E., Monaghan, J. \& Roper, T. 'Engineering students' conceptions of the derivative and some implications for their mathematical education". International Journal of Mathematical Education in Science and Technology, 38(6), 2007, pp. 763-777.

[6] Darmadi, "The Model of Visual Thinking of Prospective Math Teacher in Understanding the Formal Definition of Convergent Sequences Based on Gender Differences". Journal of Physics: Conference Series. 1417. IOP Publishing, 2019, pp. $1-8$.

[7] Darmadi Darmadi, Benny Handoyo. "Profil berpikir visual mahasiswa calon guru matematika dengan gaya belajar visual dalam menyelesaikan masalah trigonometri" Jurnal Math Educator Nusantara: Wahana Publikasi Karya Tulis Ilmiah di Bidang Pendidikan Matematika. Jilid 2. Terbitan 1, 2016.

[8] Schofield, J. W., "Increasing the generalizability of qualitative research". In E. W. Eisner \& A. Peshkin (Eds.), Qualitative inquiry in education, New York, NY: Teachers College, 1990, pp. 201-232.

[9] Sularmi, M.D. Wijayanti. "Sains 2: Ilmu Pengetahuan Alam SD/MI Kelas II”. Jakarta: Pusat Perbukuan Departemen Pendidikan Nasional, 2009.

[10] Harterich, J., Kiss, C., Rooch, A., Monnigmann, M., Darup, M. S. \& Span, R., "Mathepraxis": Connecting first-year mathematics with 
engineering applications. European Journal of Engineering Education, 37 (3), 2012, pp. 255-266.

[11] Mas Tinting Sumarni \& Siti Kamsiyati. "Asiknya belajar matematika untuk SD/MI kelas II". Ilustrasi Tiras.- Jakarta: Pusat Perbukuan Departemen Pendidikan Nasional. 2009

[12] Hasse, C., "Cultural models of physics". In O. Skovsmose, P. Valero \& O. R. Christensen (Eds.), University science and mathematics education in transition. New York, NY: Springer., 2009, pp. 109-132.

[13] Jóelsdóttir, L. B., Lindenskov, L., Misfeldt, M. \& Rattleff, P. "Economy students' learning and application of mathematics at university", Proceedings of Norma 11: The sixth Nordic conference on mathematics education, Reykjavik, Iceland: Háskólaútgáfan. 2012, pp. 339-348. 